\title{
Минералогическая зональность донных отложений Иркутского водохранилища в условиях регулируемого уровенного режима
}

\author{
Карнаухова Г.А. \\ Институт земной коры СО РАН, Иркутск, karnauh@crust.irk.ru
}

\begin{abstract}
Аннотация. В статье дается анализ минералогической зональности донных отложений Иркутского водохранилища в условиях регулируемого уровенного режима. Выделены 2 терригенно-минералогические провинции, имеющими генетическую связь с источниками поступления терригенного материала - абразионными берегами водохранилища. Питающим источником гранат-амфибол-эпидотовой провинции являются абразионные берега по левобережью водохранилища, сложенные юрскими песчаниками. По правобережью водохранилища абразия четвертичных делювиальных суглинков способствует формированию амфиболэпидот-гранатовой провинции донных осадков.

Ключевые слова: Иркутское водохранилище, донные отложения, минералогическая зональность, терригенно-минералогические провинции.

\section{Mineralogical zoning of bottom sediments of the Irkutsk reservoir under conditions of unstable level regime}

Karnaukhova G.A.

Institute of the Earth's Crust SB RAS, Irkutsk, karnauh@crust.irk.ru

\begin{abstract}
The article analyzes the mineralogical zoning of bottom sediments of the Irkutsk reservoir under conditions of unstable level regime. Two terrigenous-mineralogical provinces genetically connected with the sources of terrigenous material - abrasive shores of the reservoir-were identified. The supply source of the garnet-amphiboleepidote province is a result of abrasion of the shore on the left bank of the reservoir composed of the Jurassic sandstones. On the right bank of the reservoir, the abrasion of Quaternary deluvial loam contributes to the formation of amphiboleepidote-garnet province of bottom sediments.
\end{abstract}

Key words: Irkutsk reservoir, bottom sediments, mineralogical zoning, terrigenous-mineralogical provinces.

\section{Введение}

Иркутское водохранилище - головное в каскаде Ангарских водохранилищ, находится в эксплуатации 60 лет. Является самым маленьким в каскаде по протяженности (55 км) и объему водных масс $\left(2.1\right.$ км$\left.^{3}\right)$, площадь водохранилища при НПУ 154 км², длина береговой линии 275 км. Особенностями водохранилища является его питание водами озера Байкал, высокая проточность с водообменом 28-30 раз в год. Водохранилище является основным источником питьевого водоснабжения для городов Иркутск и Шелехов.

Осадкообразование в Иркутском водохранилище происходит в условиях регулируемого уровенного режима, что приводит к пространственным изменениям в распределении состава донных осадков и их минералогической зональности.

\section{Обстановки осадконакопления}

Основным источником формирования донных осадков являются абразионные берега водохранилища. Поступающее из озера Байкал с водным стоком тонкодисперсное рассеянное осадочное вещество проходит транзитом через водохранилище, не влияя на осадконакопление. Абразионные берега, общей протяженностью 150 км, формируются в песчаниках юрского и делювиальных отложениях четвертичного возраста.

По левобережью в средней и приплотинной частях Иркутского водохранилища песчаники, занимающие 55-75 \% разреза, представлены присаянской и черемховской свитами юры, наиболее активный размыв которых наблюдается между заливом Курма и Мельничной Падью. Протяженность абразионных берегов, сложенных песчаниками, составляет 60 км. Величина ежегодной абразии песчаников достигает 227.5 тыс. т. 
Содержание кварца в легкой фракции юрских песчаников может изменяться от 16.0 до $63.2 \%$, плагиоклазов - от 8.4 до $55.2 \%$, калишпатов - от 2.0 до $24.4 \%$. Количество слюдистого материала, состоящего по большей части из гидратизированного и хлоритизированного биотита, варьирует в пределах 8.4-61.6 \%. Ведущими минералами тяжелой фракции являются гранаты (18.1-88.1 \%), эпидот (1.0-34.4 \%), рудные (0.4-38.7 \%), присутствуют сфен (2.3-10.4 \%) и лейкоксен (2.4-11.6 \%) (Акулов и др., 2015).

Абразионные берега, сложенные четвертичными делювиальными отложениями, представлены в основном лессовидными суглинками. Протяженность размываемых берегов составляет 92 км по правобережью в средней и приплотинной частях водохранилища, т.е. примерно 21 \% от общей длины береговой линии. Максимальный их размыв происходит между пос. Патроны и плотиной Иркутской ГЭС. Поступление абразионного материала в водохранилище составляет 110 тыс. т/год.

В четвертичных делювиальных лессовидных суглинках ведущим минералом легкой фракции является кварц (60.2\%), значительно содержание полевых шпатов $(30.1 \%)$ и обломков пород $(2,2 \%)$. Основную массу $(7.5 \%)$ фракции $<0.001$ мм составляют гидрослюда и каолинит. Присутствует небольшая примесь глауконита, хлорита, опала. В составе тяжелой фракции основными минералами служат роговая обманка (50.1\%), эпидот (19.5\%) и рудные минералы (16.1\%), представленные магнетитом и ильменитом. Постоянно присутствуют гранаты (5.1\%), циркон (1.0\%), пироксены $(0.7$ \%), титаносодержащие сфен и рутил, турмалин, бурые гидроокислы (Карнаухова, 2016).

Важнейшими факторами размыва берегов и дна водохранилищ, переноса материала размыва и дифференциации его по вещественному составу являются уровенный режим водохранилища и различные волновые процессы. Режим зарегулированного притока в водохранилище отличается от его хода в естественных условиях. Транзитный сток воды из озера Байкал и эксплуатационный режим Иркутской ГЭС определяют режим уровней водохранилища.

Многолетняя изменчивость уровня воды в водохранилище проявляется в чередовании максимальных и минимальных циклов колебаний. Отметок, близких к НПУ, уровень водохранилища достигал в 1967-1974 гг., 1983-1987 гг., 1993-1995 гг., 2004-2018 гг. Стояние уровня на низких отметках пришлось на 1975-1982 гг., 1988-1992 гг., 1996-2003 гг. (Карнаухова, 2018 a; 2018 б).

Волновые процессы на Иркутском водохранилище имеют слабую и умеренную активность. По площади волнение может распространяться на всю акваторию водохранилища, по глубине только на верхнюю часть толщи воды. Мелководность и изрезанность береговой линии трансформируют волны и гасят их энергию.

\section{Осадконакопление и минералогический состав донных отложений}

Из материала абразии берегов водохранилища формируются осадки, основными типами которых являются пески, крупные алевриты и мелкоалевритовые илы. Скорость осадконакопления (мм/год) у песков составляет 0-2, крупных алевритов - 3-7, мелкоалевритовых илов - 2-6. Более высокий темп накопления осадочного материала характерен для правобережной части водохранилища, где сосредоточены абразионные берега, сложенные делювиальными суглинками.

Среди осадков наиболее тонкозернисты и хорошо сортированы пески, сформированные продуктами абразии юрских песчаников. По медианному диаметру пески приближены к крупным алевритам, зерна крупнее 0.25 мм мало встречаемы, пелитовый заполнитель составляет $8.4 \%$. В песках, формирующихся при размыве четвертичных отложений, в большей мере содержатся песчаная и крупноалевритовая фракции. Алевритовая фракция наиболее представлена (80 \%) в крупных алевритах на участках размыва суглинков. При этом незначительны в этом типе осадков доли песчаных $(13.7 \%)$ и пелитовых (6.3 \%) частиц. Мелкоалевритовые илы вблизи берегов, сложенных размываемыми песчаниками, не встречаются. Накапливаться они могут только на участках размыва четвертичных суглинков. Ведущей фракцией в них является пелитовая (36 \%), высоко количество частиц тонкопесчаной фракции (29.9 \%) (рис. 1).

Минералогический состав донных отложений Иркутского водохранилища тесно связан с источником их образования, а именно с составом пород, слагающих абразионные берега водохрани- 

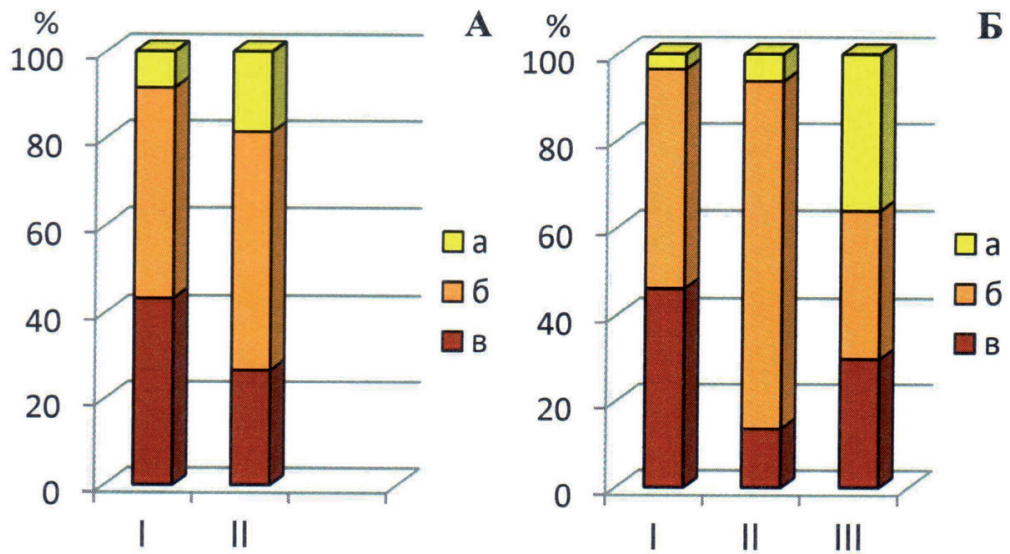

Рис. 1. Фракционный состав (\%) донных осадков Иркутского водохранилища.

Исходный материал, слагающий абразионные береговые уступы: А - юрские песчаники, Б - четвертичные суглинки. Литологический тип осадка: I - пески, II - крупные алевриты, III - мелкоалевритовые илы. Фракции: а - пелитовая, б - алевритовая, в - песчаная.

Fig. 1. Fractional composition ( $\%$ ) of bottom sediments of Irkutsk reservoir.

The Starting material composing the abrasion coastal ledges: A - Jurassic sandstones, B -Quaternary loam. Lithologic type of sediment: I - sand, II -coarse silt, III - fine-aleurites silt. Fraction: $a$ - pellite, $b$ - silt, b - sandy.

лища, а распределение минералов в осадке определяется гидродинамическими условиями в водохранилище. В минеральном составе во всех типах донных отложений лидирует легкая фракция, составляя от 99.1 до 99.7 \% в каждом образце. Основными минералами во фракции, вне зависимости от состава питающего материала, являются кварц, плагиоклазы, калишпаты. Определенные отличия есть в крупных алевритах. Так, крупные алевриты, образующиеся из четвертичных суглинков, имеют высокое содержание плагиоклазов (31.5 \%), но низкое - слюд (5.1\%) по сравнению с крупными алевритами, аккумулирующимися на участках размыва юрских песчаников, в которых по содержанию слюды стоят на втором месте после кварца (рис. 2).

Тяжелая фракция минералов более разнообразна по составу (рис. 3). Отмечается преобладание роговой обманки. Однако, по левобережью водохранилища, где наиболее распространены абра-
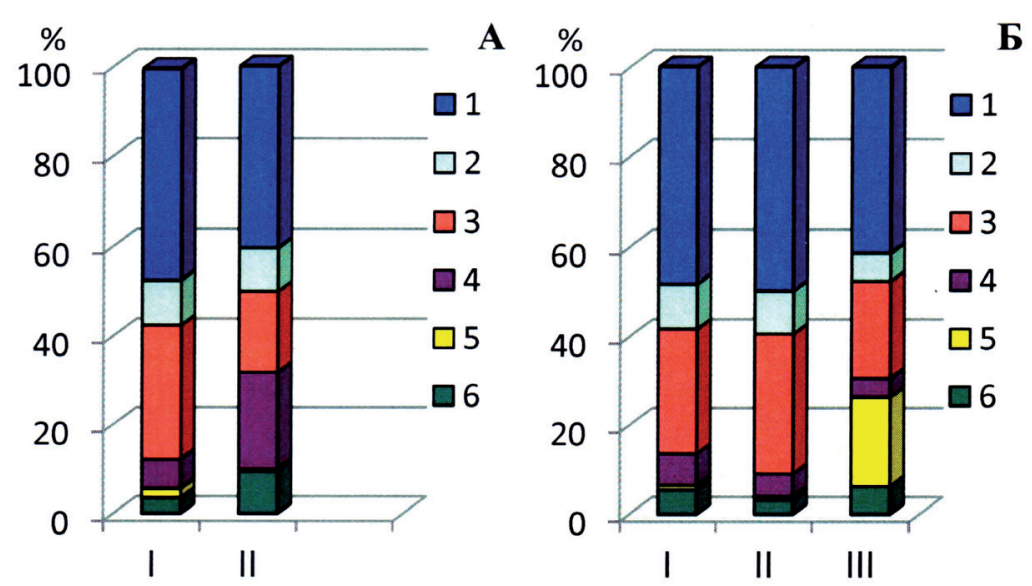

Рис. 2. Минералогический состав (\%) легкой фракции донных осадков Иркутского водохранилища. 1- кварц; 2 - калишпаты; 3 - плагиоклазы; 4 - слюды; 5 - обломки, агрегаты; 6 - углефицированные растительные остатки. Иные обозначения - см. на рис. 1.

Fig. 2. Mineralogical composition (\%) of the light fraction of bottom sediments of the Irkutsk reservoir. 1 - quartz; 2 - potash spars; 3 - plagioclase; 4 - micas; 5 - fragments, aggregates; 6 - carbonificated plant residues. Other symbols - see Fig. 1. 

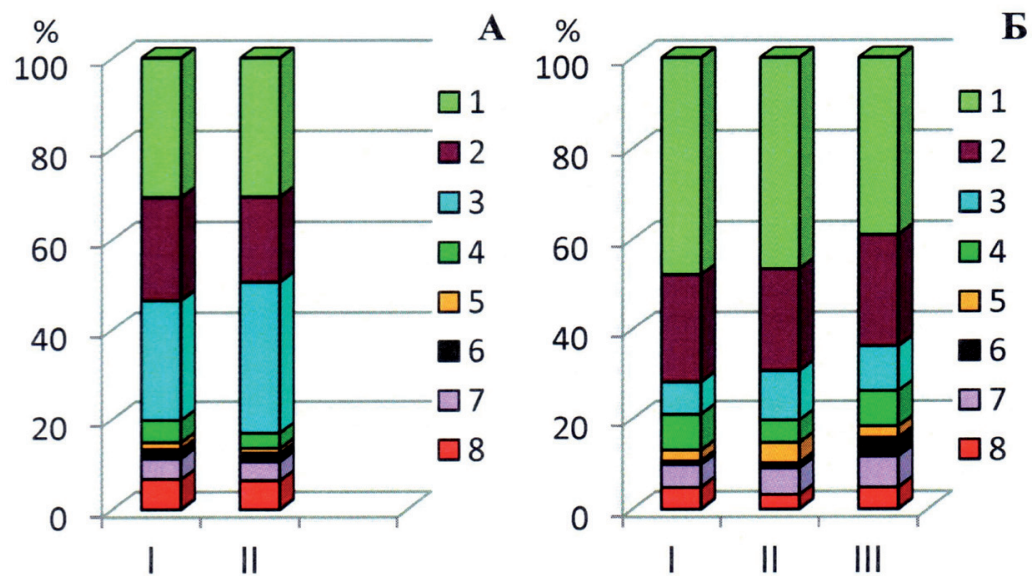

Рис. 3. Минералогический состав (\%) тяжелой фракции донных осадков Иркутского водохранилища. 1 - роговая обманка; 2 - эпидот; 3 - гранат; 4 - рудные; 5 - пироксены; 6 - циркон; 7 - сфен; 8 - прочие. Иные обозначения - см. на рис. 1 .

Fig. 3. Mineralogical composition (\%) of the heavy fraction of bottom sediments of the Irkutsk reservoir. 1 - hornblende; 2 - epidote; 3 - garnet; 4 - ore; 5 - pyroxenes; 6 - zircon; 7 - Sphene; 8 - others. Other symbols - see Fig. 1.

зионные берега, сложенные песчаниками, ведущим минералом является гранат, содержание которого составляет от 26.7 \% в песках до 33.7 \% в крупных алевритах. По правобережью же, с его преобладанием абразии берегов в отложениях четвертичного возраста, в донных отложениях за роговой обманкой, количества которой значительно больше, чем в осадках левобережья, следует эпидот, составляя 22.8-24.8 \%. Количество граната не превышает 11 \%. Осадки более насыщены ильменитом и магнетитом, сфеном.

Таблица. Распределение некоторых минералов тяжелой фракции в донных осадках по терригенно-минералогическим провинциям Иркутского водохранилища.

Table. The distribution of certain minerals of the heavy fraction in bottom sediments for terrigenous-mineralogical provinces of the Irkutsk reservoir.

\begin{tabular}{|c|c|c|c|c|c|}
\hline \multirow{4}{*}{ Минералы } & \multicolumn{5}{|c|}{ Терригенно-минералогическая провинция } \\
\hline & \multicolumn{2}{|c|}{ Гранат-амфибол-эпидотовая } & \multicolumn{3}{|c|}{ Амфибол-эпидот-гранатовая } \\
\hline & \multicolumn{5}{|c|}{ Тип осадка } \\
\hline & Пески & Крупные алевриты & Пески & $\begin{array}{l}\text { Крупные } \\
\text { алевриты }\end{array}$ & $\begin{array}{c}\text { Мелкоалевритовые } \\
\text { илы }\end{array}$ \\
\hline Амфиболы & 30.7 & 30.6 & 47.8 & 46.5 & 39.0 \\
\hline Эпидот & 22.8 & 18.8 & 24.0 & 22.8 & 24.8 \\
\hline Гранат & 30.0 & 33.7 & 7.8 & 11.0 & 10.0 \\
\hline Рудные & 5.0 & 3.4 & 8.0 & 5.0 & 7.1 \\
\hline Пироксены & 0.1 & 0.1 & 2.4 & 4.8 & 2.5 \\
\hline Циркон & 0.2 & 0.2 & 0.2 & 0.2 & 4.9 \\
\hline Сфен & 4.6 & 3.8 & 5.0 & 6.5 & 6.8 \\
\hline Прочие & 6.6 & 6.3 & 4.8 & 3.2 & 4.9 \\
\hline
\end{tabular}

Разнос и дифференциация терригенного материала по водохранилищу способствуют минералогической зональности в распределении донных осадков. По пространственному группированию минералов тяжелой фракции в донных осадках водохранилища нами выделяются 2 основные терригенно-минералогические провинции, имеющие генетическую связь с источниками поступления осадкообразующего материала (таблица). С юрскими песчаниками связана гранат-амфиболэпидотовая провинция донных осадков. Донные осадки в гранат-амфибол-эпидотовой провинции обогащены слюдистым материалом и количественно превышают по содержанию граната осадки 
амфибол-эпидот-гранатовой провинции, но уступают по концентрации рудных минералов, пироксенов, диопсида, полевых шпатов, особенно плагиоклазов. Рудные минералы осаждаются в узкой прибрежной полосе водохранилища. По содержанию минералов в легкой фракции донные осадки провинции имеют большее количество обломков и агрегатов.

Абразия делювиальных суглинков способствует формированию в донных отложениях амфибол-эпидот-гранатовой терригенно-минералогической провинции. Количество роговой обманки более чем на $10 \%$ превышает таковое в гранат-амфибол-эпидотовой провинции. В мелкоалевритовых илах этой провинции наиболее активно концентрируются циркон, сфен. Характерной для осадков провинции является присутствие в осадках гиперстена. По направлению к плотине количество устойчивого граната в осадках обеих провинций возрастает и снижается содержание циркона.

Таким образом, полученные данные свидетельствуют о том, что наиболее активно минералы тяжелой фракции накапливаются в донных осадках приплотинной части Иркутского водохранилища. Состав материала, слагающего абразионные берега водохранилища, отражается в закономерном распределении минералов тяжелой фракции донных отложений и в терригенно-минералогических провинциях, имеющие генетическую связь с питающими источниками.

Работа выполнена при финансовой поддержке РФФИ (проект № 18-05-00101).

\section{Литература}

1. Акулов Н.И., Фролов А.О, Мащук И.М., Акулова В.В. Юрские отложения южной части Иркутского осадочного бассейна // Стратиграфия. Геологическая корреляция. 2015. Т. 23. № 4. С. 1-24.

2. Карнаухова Г.А. Вещественный состав донных отложений в прибрежной зоне Иркутского водохранилища // Изв. ИГУ. Сер. «Науки о Земле». 2016. Т. 17. С. 64-77.

3. Карнаухова Г.А. Трансгрессивно-регрессивные циклы осадконакопления в водохранилищах Ангарского каскада как следствие «навязанного» уровенного режима // Осадочная геология Урала и прилежащих регионов: сегодня и завтра / Материалы 12 Уральского литологического совещания. Екатеринбург: ИГГ УрО РАН. 2018 a. С. 122-124.

4. Карнаухова Г.А. Управляемый уровенный режим как ведущий фактор цикличности трансгрессивнорегрессивного осадкообразования в водохранилищах Ангарского каскада // International Conference «Freshwater Ecosystems - Key Problems». 10-14 September. 2018 / Abstracts / Irkutsk: LLC «Megaprint», 2018 б. C. 178-179. 